\title{
PENGARUH UNGKAPAN SYUKUR DAN MOTIVASI TERHADAP PERILAKU PROSOSIAL REMAJA
}

\author{
Nurul Fitroh*, Lukman, \& Muh. Nur Hidayat Nurdin \\ Fakultas Psikologi, Universitas Negeri Makassar, Makassar \\ *Email: nurulfitroh13@gmail.com
}

\begin{abstract}
Abstrak
Penelitian ini bertujuan untuk mengetahui perbedaan perilaku prososial remaja yang memiliki motivasi autonomous dan controlled serta yang menerima dan tidak menerima ungkapan syukur. Partisipan penelitian ini melibatkan 94 Siswa SMA berusia 15-18 tahun. Melalui metode eksperimen penelitian ini menggunakan factorial design with two betweensubjects independent variabels. Hasil penelitian menunjukkan, pertama, remaja yang memiliki motivasi autonomous memiliki intensi perilaku prososial yang lebih baik dibandingkan dengan remaja yang memiliki motivasi controlled. Kedua, tidak terdapat perbedaan intensi perilaku prososial pada remaja yang menerima ungkapan syukur dan tidak menerima ungkapan syukur. Ketiga, tidak ada interaksi antara motivasi dan ungkapan syukur terhadap intensi perilaku prososial pada remaja. Penelitian ini dapat dijadikan bahan diskusi lanjutan untuk mengetahui alasan ungkapan syukur tidak berpengaruh pada perilaku prososial remaja yang pada umumnya bisa memberikan pengaruh.
\end{abstract}

Kata kunci: Perilaku prososial; motivasi autonomous; motivasi controlled; ungkapan syukur; remaja.

\begin{abstract}
This study aims to determine the differences of prosocial behaviour intention in adolescents who have autonomous and controlled motivation and who receive and do not receive expressions of gratitude. Participants in this study involved 94 high school students, 15-18 years old. Through the experimental method, this research uses factorial design with two between-subjects independent variables. The results showed, first, adolescents who had autonomous motivation had better prosocial behavior intentions than those with controlled motivation. Second, there is no difference in prosocial behavior intentions among adolescents who receive gratitude expressions and do not receive gratitude expressions. Third, there is no interaction between motivation and expressions of gratitude towards prosocial behavior intentions in adolescents. This research can be used as a matter of further discussion to find out the reason for the expression of gratitude that does not affect the prosocial behaviour that generally found influencing in adolescents.
\end{abstract}

Keywords: Prosocial behaviour; autonomous motivation; controlled motivation; expressions of gratitude; adolescence.

\section{Pendahuluan}

Sebagai emosi, syukur dapat menjadi pengalaman universal, namun setiap budaya menunjukkan perbedaan konsep dan strategi dalam mengekspresikan perasaan tersebut. (Floyd dkk., 2018).
Sekalipun terdapat perbedaan dalam mengekspresikan syukur, hampir semua budaya menganggap syukur sebagai sebuah nilai kebaikan (virtue) yang diharapkan di dalam masyarakat (Mercon- 
Vargas, Poelker, Jonathan \& Tudge, 2018).

Di dalam masyarakat Brazil, ungkapan syukur secara verbal adalah strategi yang paling umum dilakukan (Palhares, Freitas, Vargas \& Tudge, 2018). Sedangkan pada masyarakat Cina dan Korea Selatan, ekspresi syukur connective yaitu membalas kebaikan benefactor dengan sesuatu yang diharapkan atau yang mungkin dibutuhkan oleh benefactor, menjadi strategi yang diutamakan (Mendonça, Mercon-Vargas dkk., 2018). Lain lagi pada masyarakat Jepang, yang memiliki ungkapan 'sumimasen' dalam menunjukkan rasa tidak enak diri karena telah memberatkan pihak lain dalam menolongnya (Naito \& Washizu, 2015).

Penelitian sebelumnya (Palhares dkk., 2018; Mendonca dkk., 2017; Naito \& Washizu, 2015) menjelaskan pentingnya pengaruh budaya dalam memaknai dan mengekspresikan syukur. Syukur sebagai virtue jelas memiliki peran penting dalam hubungan interpersonal, sebab bukan hanya menelusuri perasaan beneficiary saja, namun juga melibatkan penelusuran hubungan resiprokal antara benefactor dan beneficiary. Indonesia adalah negara yang terkenal akan ragam suku, budaya, etnis, dan agamanya. Dalam beberapa budaya terdapat istilah khusus dalam mengungkapkan syukur, misalnya dalam budaya Jawa, 'matur nuwun', Sunda 'hatur nuhun', dan Batak 'mauliate'. Sedangkan ada pula yang tidak memiliki istilah khusus dalam mengungkapkan syukur, misalnya pada suku Bugis, namun bukan berarti mereka tidak memiliki konsep terhadap syukur. Suku Bugis dan Makassar dapat memaknai syukur dan menerapkannya dalam kehidupan seharihari (Fitroh, Kurniawan, Azizah, Pratama, \& Ahyar, 2016).

Di Indonesia penelitian psikologi dalam kajian syukur telah dilakukan. Misalnya terdapat studi mengenai makna syukur pada mahasiswa (Haryanto \& Kertamuda, 2016; Kusumastuti, Setyorini
\& Laksono, 2017) lalu konsep dan konstruk syukur dalam psikologi islam (Rusdi, 2016), dan pengembangan skala bersyukur di Indonesia (Listiyandini, Nathania, Syahniar, Sonia \& Nadya, 2015). Terdapat juga beberapa penelitian yang mengaitkan syukur dengan tema berbeda, misalnya syukur dan perilaku prososial (Wicaksono \& Susilawati, 2016) serta syukur dan well-being (Sativa \& Helmi, 2013)

Penelitian sebelumnya belum secara spesifik melihat ekspresi syukur dalam konteks hubungan interpersonal. Padahal terdapat manfaat sosial yang besar dibalik ekspresi syukur, salah satunya adalah perilaku prososial. Syukur interpersonal merupakan kondisi ketika individu mengakui bahwa dirinya telah menerima sesuatu yang berharga dari orang lain (Emmons, 2012). Mengekspresikan syukur akan menimbulkan selfworth pada orang yang menerimanya (Grant \& Gino, 2010). Ekspresi syukur bisa dinyatakan melalui ekspresi wajah maupun ungkapan verbal (Naito, Wangwan, \& Tani, 2005) dan dalam bentuk tulisan (Grant \& Gino, 2010). Apa pun bentuk ekspresi tersebut, Naito dkk. (2005); Grant dan Gino (2010) secara bersama-sama menemukan bahwa ekspresi syukur berkorelasi positif dengan perasaan positif dan motivasi untuk melakukan perilaku prososial. Grant dan Gino (2010) menemukan bahwa dalam hubungan interpersonal, perilaku prososial bisa muncul karena ungkapan syukur. Individu yang menerima ungkapan syukur akan membuat individu tersebut mempertahankan perilaku prososialnya di kesempatan lain. Yoshimura dan Berzins (2017) juga mengungkapkan pentingnya mengungkapkan rasa syukur dalam hubungan sosial sebagai upaya meningkatkan well-being seseorang.

Melalui penelitian Grant dan Gino (2010), kita dapat melihat reaksi yang diperoleh benefactor saat menerima ungkapan syukur, dalam arti lain, penelitian tersebut memungkinkan kita melihat syu 
kur dalam fungsi reinforcer yang berasal dari faktor eksternal sehingga dapat mempertahankan perilaku prososial benefactor (McCullough, Kilpatrick, Emmons, \& Larson, 2001). Namun, kita belum melihat faktor internal yang dimiliki benefactor itu sendiri, yakni motivasinya. Sedangkan dalam hubungan resiprokal kita juga perlu menelusuri bagaimana kondisi internal benefactor saat melakukan perilaku prososial. Dorongan internal yang berbeda dapat pula memberikan efek psikologis berbeda pada diri seseorang dalam perilaku prososial.

Menurut Kim, Dyne, dan Lee (2018) dalam salah satu studinya, motivasi autonomous membuat benefactor memiliki kondisi emosi yang lebih positif saat melakukan perilaku menolong. Hal tersebut, menurut Deci dan Ryan (2000) terjadi karena individu berhasil merefleksikan diri sebagaimana mestinya, dan dalam atribusinya melakukan internal perceived locus of causality (IPLOC). Deci, La Guardia, Moller, Scheiner dan Ryan (2006) juga mengemukakan bahwa dalam hubungan interpersonal, memberikan dukungan autonomy, dan menerima dukungan autonomy akan membuat kualitas hubungan menjadi lebih baik dan efek psikologis yang lebih sehat.

Penelitian lain mengenai motivasi dalam menolong dengan membandingkan antara motivasi autonomous dan controlled, membuktikan bahwa motivasi autonomous memberikan individu performa yang lebih baik, juga self-esteem dan well-being yang lebih tinggi dibandingkan dengan motivasi controlled (Weinstein \& Ryan, 2010), bahkan memberi reaksi positif terhadap beneficiary (Weinstei, DeHaan, \& Ryan, 2010) begitupun yang ditemukan oleh Pavey, Greitemeyer dan Sparks (2012) bahwa perilaku menolong dan tingkat empati lebih tinggi dimiliki oleh individu yang berada dalam kondisi autonomous dibanding pada individu yang berada pada kondisi controlled, hal tersebut karena jika dalam motivasi controlled seseorang akan merasakan kondisi diri yang terkontrol dan tertuntut oleh situasi, dalam motivasi autonomous, seseorang akan berada pada kondisi perasaan bebas dan senang dalam melakukan sesuatu.

Individu yang setiap perilakunya didukung oleh kondisi autonomous dan setiap perilakunya di lingkungan dihargai dengan menerima ungkapan rasa atas perilaku yang ia lakukan, maka ia tidak hanya akan berada pada kondisi penilaian diri yang baik namun juga akan merasakan penguatan emosi positif hal tersebut menjadi moral barometer dan reinforcer (McCullough, dkk. 2001). Ketika perilaku prososial dibutuhkan individu yang berada dalam kondisi autonomous dan menerima ungkapan syukur akan memberikan performa yang lebih baik, hal ini pun dapat terjadi jika ungkapan syukur tersebut dirasakan melalui proses immerse yang baik, dibandingkan dengan kelompok yang berada dalam kondisi controlled dan perilaku mereka tidak dihargai dengan tidak hadirnya ungkapkan syukur.

Penelitian ini akan memberikan pandangan baru terhadap kajian mengenai syukur dan berfokus pada ungkapan syukur secara verbal dalam perilaku prososial remaja, sekaligus juga melihat keterlibatan peran motivasi yang secara internal dapat mempengaruhi perilaku prososial remaja. Maka dari itu, penelitian ini memiliki tiga hipotesis, pertama terdapat perbedaan intensi perilaku prososial pada individu dalam kondisi autonomous dan individu dalam kondisi controlled. Individu dengan motivasi autonomous akan lebih tinggi intensi perilaku prososialnya. Kedua, terdapat perbedaan intensi perilaku prososial pada individu yang menerima ungkapan syukur dan individu yang tidak menerima ungkapan syukur. Individu yang menerima ungkapan syukur dari orang lain akan lebih tinggi intensi perilaku prososialnya. Ketiga, terdapat perbedaan perilaku prososial pada individu dalam kondisi autonomous dan individu dalam kondisi controlled ketika 
menerima dan tidak menerima ungkapan syukur. Individu yang mendapat ungkapan syukur dan berada pada kondisi autonomous lebih tinggi intensi perilaku prososialnya dibanding kelompok yang lain

\section{Metode Penelitian}

Partisipan. Total partisipan dalam penelitian berjumlah 120 orang siswa SMA. Diperoleh melalui izin dari pihak sekolah yang memberikan daftar kelas dan siswa yang dapat berpartisipasi. Partisipan berusia 15-18 tahun. Berdasarkan hasil uji manipulation check, terdapat 26 partisipan yang tidak memenuhi syarat analisis sehingga menghasilkan 94 partisipan yang dapat di analisis datanya. Setiap partisipan mengisi lembar informed consent dan mendapatkan imbalan voucher diskon belanja buku.

Desain. Penelitian ini menggunakan desain faktorial 2 (motif menolong: autonomous; controlled) x 2 (ungkapan syukur: menerima ungkapan terima kasih; tidak menerima ucapan terima kasih) between participants dengan random assignment.

Manipulasi. Terdapat 4 buah narasi untuk empat kelompok. Narasi dibuka dengan instruksi "Anda diminta untuk berperan sebagai orang yang mengalami kejadian dalam narasi cerita berikut ini." lalu diawali dengan cerita,

"Hari ini diadakan persiapan kelulusan siswa kelas tiga. Kamu bertugas untuk mempersiapkan ruangan aula di sekolah bersama beberapa siswa lainnya. Setelah tugas mu selesai kamu melihat seorang guru mengangkat beberapa barang menggunakan dus ke ruang guru, ia memanggilmu untuk membantu"

Kelompok I kondisi motivasi autonomous tanpa ungkapan terima kasih, dilanjutkan "dan dengan keinginan sendiri, secara senang hati kamu membantunya". Kelompok II kondisi motivasi autonomous dengan ungkapan terima kasih, dilanjutkan "secara senang hati kamu membantunya. Setelah itu gurumu mengucapkan terima kasih, ia bersyukur karena kamu telah membantunya." Kelompok III kondisi motivasi controlled tanpa ungkapan terima kasih dilanjutkan dengan, "karena tidak enak menolak dan merasa bersalah jika menolak, maka kamu terpaksa menolongnya". Kelompok IV kondisi motivasi controlled dengan ungkapan terima kasih, dilanjutkan dengan "karena tidak enak menolak dan merasa bersalah jika menolak, maka kamu terpaksa menolongnya. Setelah itu gurumu mengucapkan terima kasih, ia bersyukur karena kamu telah membantunya." Cerita berlanjut dengan dua lagi pengalaman membantu yaitu kepada kakak kelas dan seorang teman, dengan motivasi dan ungkapan yang sesuai untuk masing-masing kelompok.

Manipulation Check. Manipulation check ungkapan syukur diukur dengan kesadaran partisipan menyimak ungkapan terima kasih, sejumlah 60 partisipan dalam kelompok menerima ungkapan terima kasih ditemukan 55 partisipan yang berada pada kondisi yang sesuai. Sejumlah 60 partisipan dalam kelompok tanpa ungkapan terima kasih ditemukan 39 partisipan yang berada pada kondisi yang sesuai.

Manipulation check motivasi diukur melalui kesadaran partisipan atas motivasinya dalam melakukan perilaku membantu atau menolong. Sejumlah 60 partisipan dalam kelompok motivasi autonomous ditemukan 43 yang berada pada kondisi yang diinginkan. Sejumlah 60 partisipan dalam kelompok motivasi controlled ditemukan 51 partisipan yang berada pada kondisi yang sesuai.

Skala Intensi Perilaku Sosial. Data dalam penelitian ini dikumpulkan dengan menggunakan skala intensi perilaku prososial. menggunakan konsep narasi perilaku prososial yang diadaptasi dari penelitian Albrecht (2016). Skala terdiri dari 6 item menggunakan 5-point rating scale. Hasil uji reliabilitas menunjukkan nilai Cronbach's alpha=0,79. 
Tabel 1. Hasil uji analysis of variance

\section{Tests of Between-Subjects Effects}

\begin{tabular}{lrrrrr}
\hline Dependent Variable: & Prosos & & & & \\
\hline & & & & & \\
Source & Type III Sum of Squares & df & Square & F & Sig. \\
Corrected Model & $88.596^{a}$ & 3 & 29,532 & 2,764 &, 047 \\
Intercept & 13404,519 & 1 & 13404,519 & 1254,658 &, 000 \\
Motivasi & 67,850 & 1 & 67,850 & 6,351 &, 013 \\
Ungkapan &, 783 & 1 &, 783 &, 073 &, 787 \\
Motivasi * Ungkapan & 9,370 & 1 & 9,370 &, 877 &, 352 \\
Error & 961,543 & 90 & 10,684 & & \\
Total & 14803,000 & 94 & & & \\
Corrected Total & 1050,138 & 93 & & & \\
\hline
\end{tabular}

a. R Squared $=.084$ (Adjusted R Squared $=.054$ )

Tabel 2. Marginal mean motivasi dan ungkapan syukur

\begin{tabular}{lllrrrr}
\hline \multirow{2}{*}{ Motivasi } & & & & \multicolumn{2}{c}{$95 \%$ Confidence Interval } \\
\cline { 6 - 7 } & & Mean & Std. Error & Lower Bound & $\begin{array}{c}\text { Upper } \\
\text { Bound }\end{array}$ \\
\hline Autonomous & Terima & 13,440 &, 654 & 12,141 & 14,739 \\
& Tidak & 12,611 &, 770 & 11,081 & 14,142 \\
Controlled & Terima & 11,067 &, 597 & 9,881 & 12,252 \\
& Tidak & 11,524 &, 713 & 10,107 & 12,941
\end{tabular}

Dependent Variable: Prosos

\section{Hasil}

Melalui uji ANAVA ditemukan bahwa $\left(\mathbf{H}_{1}\right)$ Terdapat perbedaan intensi perilaku prososial pada individu dalam kondisi autonomous dan individu dalam kondisi controlled. Kondisi motivasi autonomous signifikan memiliki intensi perilaku prososial yang lebih tinggi dibandingkan dengan motivasi controlled, dengan nilai $F(6,351)=0,013, p>.05$. Kelompok autonomous memiliki nilai $(M=13,09, S D$ $=3,551)$, dan controlled $(M=11,25, S D=$ 2,972). $\left(\mathbf{H}_{\mathbf{2}}\right)$ Terdapat perbedaan intensi perilaku prososial pada individu yang menerima ungkapan syukur dan individu yang tidak menerima ungkapan syukur. Tabel 14 menunjukkan kondisi menerima ungkapan syukur dan tidak menerima ungkapan syukur menunjukkan perbedaan yang tidak signifikan dengan nilai $F(0,073)=0,787, p>.05$. Kelompok menerima ungkapan memiliki nilai $(M=$ $12,15, S D=3,556)$, dan tidak menerima ungkapan $(M=12,03, S D=3,018) .\left(\mathbf{H}_{3}\right)$ Terdapat perbedaan perilaku prososial pada individu dalam kondisi autonomous dan individu dalam kondisi controlled ketika menerima ungkapan syukur dan tidak menerima ungkapan syukur. Uji interaksi menunjukkan bahwa tidak ada interaksi antara motivasi dan ungkapan syukur dengan nilai $F(0,877)=0,352, p>.05$. 


\section{Diskusi}

Hasil analisis data menunjukkan bahwa motivasi autonomous memberikan intensi perilaku prososial yang lebih tinggi dibandingkan motivasi controlled. Hal ini terjadi karena individu yang memiliki kuasa atas pilihannya dalam melakukan sesuatu akan memiliki perasaan senang. Kebutuhan autonomy yang terpenuhi, melengkapi kebutuhan competence (berhasil menolong orang lain) dan relatedness (terlibat dalam interaksi dengan orang lain). Sedangkan, individu yang terpaksa melakukan sesuatu, sekalipun merasakan competence dan relatedness, namun karena bukan oleh pilihan sendiri, melainkan karena adanya tekanan dari luar, membuat individu melakukan sesuatu dengan perasaan yang berat hati, sehingga memungkinkan memberi pengaruh terhadap perilaku prososial di kesempatan lain.

Seperti penelitian yang dilakukan Weinstein dan Ryan (2010). Penelitiannya melibatkan 124 partisipan dan membagi secara random ke dalam dua kelompok yakni kelompok autonomous dan controlled untuk melihat motivasi menolong mengangkat paket saat mereka sedang beristirahat. Motivasi menolong dilihat berdasarkan hasil efektifitas menolong yang dinilai oleh penerima bantuan, bahwa kelompok autonomous memberikan pertolongan mengangkat paket yang lebih banyak dibanding kelompok controlled.

Penelitian lain, masih dalam konteks perilaku prososial yang dilakukan Gagné (2003) terhadap 121 partisipan, menemukan bahwa kecenderungan perilaku prososial yang tinggi khususnya bergabung pada kegiatan kesukarelawanan, didukung oleh motivasi autonomous. Motivasi autonomous memberikan motivasi yang lebih tinggi dibanding kondisi controlled. Pavey dkk. (2012) juga melakukan penelitian terhadap 70 partisipan dan mengungkapkan bahwa perilaku memberikan bantuan dan tingkat empati yang lebih tinggi dimiliki oleh individu yang berada dalam kondisi autonomous dibanding pada individu yang berada pada kondisi controlled. Studi selanjutnya dalam penelitian tersebut yang melibatkan 166 partisipan mendukung studi sebelumnya bahwa motivasi autonomous membuat partisipan memiliki intensitas dan perilaku prososial yang lebih tinggi.

Dalam ungkapan syukur hasil menunjukkan bahwa tidak ada perbedaan yang signifikan antara kelompok yang menerima ungkapan syukur dan yang tidak menerima ungkapan syukur. Fenomena tersebut menjukkan bahwa tidak seperti yang diduga sebelumnya, ungkapan syukur ternyata tidak secara signifikan mempengaruhi perilaku prososial. Melalui hasil tersebut, kita dapat mengetahui sudut pandang baru mengenai ungkapan syukur. Menurut pengamatan peneliti hal tersebut dapat terjadi karena faktor budaya yang mempengaruhi ungkapan syukur. Naito dan Washizu (2015) mengemukakan bahwa budaya memberi pengaruh penting dalam memaknai ungkapan syukur. Partisipan penelitian ini tinggal dalam lingkungan budaya Bugis dan Makassar. Berdasarkan penelitian dari Fitroh, dkk. (2016) mengungkapkan bahwa ungkapan terima kasih interpersonal menjadi ekspresi yang jarang dilakukan oleh remaja Bugis dan Makassar. Hal tersebut menunjukkan bahwa ungkapan syukur dalam bentuk ucapan terima kasih tidak memiliki arti yang begitu dalam. Budaya Bugis-Makassar dalam mengungkapkan syukur interpersonal lebih kepada strategi balas budi. Jika seseorang memberikan sebuah bantuan atau hadiah, yang terjadi adalah perasaan wajib balas budi.

Penelitian yang dilakukan oleh Naito dkk. (2005) bahwa dalam masyarakat asia perasaan indebtedness atau berutang budi memiliki peranan yang besar dalam melakukan perilaku prososial. Pengalaman melakukan perilaku menolong lebih besar jika sebelumnya individu telah mendapatkan pertolongan dari individu lain. Sementara dalam penelitian ini individu tidak mendapatkan pengalaman 
serupa, melainkan partisipan berulang kali melakukan perilaku menolong dan membantu dan mendapat ungkapan terima kasih atas bantuannya.

Strategi dalam mengungkapkan syukur juga berbeda dalam tiap budaya. Pishghadam dan Zarei (2012) melakukan penelitian terhadap 250 pelajar yang memiliki berasal dari latar belakang budaya berbeda dan menggunakan Bahasa berbeda, yakni Persia, Cina dan Inggris. Secara signifikan partisipan menunjukkan adanya perbedaan strategi dalam mengungkapkan syukur. Partisipan Inggris dibandingkan Cina dan Persia, lebih mudah mengungkapkan syukur dalam bentuk verbal dan frekuensinya pun lebih sering. Partisipan Persia lebih sering mengaitkan ungkapan syukur dengan sesuatu yang berhubungan dengan kepercayaan agama 'Semoga Tuhan membalas kebaikanmu' atau memuji orang lain 'matamu sangat indah'. Partisipan Cina menunjukkan strategi balas budi yang lebih tinggi misalnya menawarkan makan dan lainnya.

Melalui hasil penelitian juga diketahui bahwa kelompok controlled yang tidak menerima ungkapan terima kasih memiliki intensi perilaku prososial yang lebih tinggi dibandingkan dengan kelompok controlled tanpa ungkapan terima kasih. Hal tersebut menunjukkan bahwa ungkapan terima kasih juga tidak memberikan pengaruh ketika individu berada dalam kondisi controlled. Ungkapan syukur yang tidak mampu dirasakan oleh benefactor tidak dapat memenuhi fungsi ungkapan syukur yang sebenarnya (Dwyer, 2015). Kehilangan pemaknaan ekspresi syukur juga bisa terjadi karena individu sudah merasakan kondisi kontrol. Deci dan Ryan (2000) mengungkapkan bahwa kondisi controlled yang memberikan efek keterpaksaan membuat seseorang melakukan regulasi jenis introjection, yang berarti tidak terjadi integrasi antara sesuatu yang dilakukan dan perasaan individu, membuat sesuatu yang dilakukan berada diluar orientasi diri (self) yang sebenarnya. Sehingga apapun yang diterima yang berasal dari luar dirinya menjadi sulit di integrasikan. Kekurangan penelitian ini adalah karena tidak mengukur sebarapa besar intensi motivasi dan ungkapan yang dirasakan, melainkan hanya melakukan cek apakah partisipan berada dalam kondisi motivasi autonomous atau controlled dan menerima ungkapan terima kasih atau tidak, sehingga dapat diasumsikan bahwa efek controlled bisa jadi memberikan kondisi yang kuat.

\section{Kesimpulan}

Berdasarkan hasil penelitian yang telah didapat, maka dapat disimpulkan bahwa (1) Motivasi autonomous memberikan pengaruh yang signifikan lebih baik terhadap intensi perilaku prososial remaja dibandingkan dengan motivasi controlled. (2) Tidak terdapat perbedaan yang signifikan antara menerima ungkapan syukur dan tidak menerima ungkapan syukur terhadap intensi perilaku prososial remaja. (3) Tidak terdapat perbedaan yang signifikan antara kelompok motivasi autonomous yang menerima ungkapan terima kasih dengan yang tidak menerima ungkapan terima kasih dan tidak terdapat perbedaan yang signifikan antara kelompok motivasi controlled yang menerima ungkapan syukur dengan yang tidak menerima ungkapan syukur.

\section{Daftar Pustaka}

Albrecht, C. (2016). The effect of reading narratives: How does perspective taking influence prosocial behavior? (Bachelor's thesis, University of Twente). Retrieved from https://essay.utwente.nl/70084/1/Albr echt_BA_BMS.pdf

Deci, E. L., La Guardia, J. G., Moller, A. C., Scheiner, M. J., \& Ryan, R. M. (2006). On the benefits of giving as well as receiving autonomy support: Mutuality in close friendship. Personality and Social Psychology 
Bulletin, 32(3), 313-327. doi: $10.1177 / 0146167205282148$

Deci, E. L., \& Ryan, R. M. (2000). The" what" and" why" of goal pursuits: Human needs and the selfdetermination of behavior. Psychological Inquiry, 11(4),227-268. doi: 10.1207/S15327965PLI1104_01

Emmons, R. A. (2012). Queen of the virtues? Gratitude as human strength. Reflective practice: Formation and supervision in ministry, 32. Retrieved from

http://journals.sfu.ca/rpfs/index.php/rp fs/article/view/59

Fitroh, N., Kurniawan, W., Azizah, A., Pratama, B., \& Ahyar, M. (2016). Mengapa remaja Bugis Makassar bersyukur?: Pendekatan indigenous psychology. INQUIRY Jurnal IImiah Psikologi, 7(2), 62-75. Retrieved from http://journal.paramadina.ac.id/index. php/inquiry/article/view/101

Floyd, S., Rossi, G., Baranova, J., Blythe, J., Dingemanse, M., Kendrick, K. H., Zinken, J., \& Enfield, N. J. (2018). Universals and cultural diversity in the expression of gratitude. Royal Society open science, 5(5), 180391. doi: $10.1098 /$ rsos. 180391

Gagné, M. (2003). The role of autonomy support and autonomy orientation in prosocial behaviour engagement. Motivation and Emotion, 27(3), 199-233. doi: 10.1023/A:1025007614869

Grant, A. M., \& Gino, F. (2010). A little thanks goes a long way: Explaining why gratitude expressions motivate prosocial behavior. Journal of Personality and Social Psychology, 98(6), 946-955. doi: 10.1037\%2Fa0017935

Haryanto, H. C., \& Kertamuda, F. E. (2018). Syukur sebagai sebuah pemaknaan. Insight, 18(2). Retrieved from http://ejurnal.mercubuanayogya.ac.id/index.php/psikologi/article /view/395

Kim, Y. J., Van Dyne, L., \& Lee, S. M. (2018). A dyadic model of motives, pride, gratitude, and helping. Journal of Organizational Behavior. doi: 10.1002/job.2315

Kusumastuti, W., Setyorini, N., \& Laksono, R. A. (2017, November). Makna kebersyukuran berdasarkan kajian psikologis dan kajian tafsir al-misbah. Seminar Nasional Bahasa, Sastra, dan Budaya. (Vol. 1, No. 01). Retrieved from http://eproceedings.umpwr.ac.id/inde x.php/bahtera/article/view/48

Listiyandini, R. A., Nathania, A., Syahniar, D., Sonia, L., \& Nadya, R. (2015). Mengukur rasa syukur: Pengembangan model awal skala bersyukur versi Indonesia. Jurnal Psikologi Ulayat: Indonesian Journal of Indigenous Psychology, 2(2), 473-496. Retrieved from http://jpu.kpin.org/index.php/jpu/article/view/41

McCullough, M. E., Kilpatrick, S. D., Emmons, R. A., \& Larson, D. B. (2001). Is gratitude a moral affect? Psychological Bulletin, 127(2), 249-266. doi: 10.1037//0033-2909.127.2.249

Mendonça, S. E., Merçon-Vargas, E. A., Payir, A., \& Tudge, J. R. (2018). The development of gratitude in seven societies: Cross-cultural highlights. CrossCultural Research, 52(1), 135-150. doi: $10.1177 / 1069397117737245$

Mercon-Vargas, E. A., Poelker, K. E., \& Tudge, J. R. (2018). The development of the virtue of gratitude: Theoretical foundations and cross-cultural issues. Cross-Cultural Research, 52(1), 3-18. doi: $10.1177 / 1069397117736517$

Naito, T., Wangwan, J., \& Tani, M. (2005). Gratitude in university students in Japan and Thailand. Journal of CrossCultural Psychology, 36(2), 247-263. doi: $10.1177 / 0022022104272904$

Naito, T., \& Washizu, N. (2015). Note on cultural universals and variations of gratitude from East Asian point of view. International Journal of Behavioral Science, 10(2), 1-8. doi: 10.14456/ijbs.2015.38

Dwyer, P. C. (2015). Gratitude as Persuasion: Understanding When and 
Why Gratitude Expressions Facilitate and Inhibit Compliance. Retrieved from https://conservancy.umn.edu/handle/ 11299/175125

Palhares, F., Freitas, L. B., MerçonVargas, E. A., \& Tudge, J. R. (2018). The development of gratitude in Brazilian children and adolescents. Cross-Cultural Research, 52(1), 3143. doi: $10.1177 / 1069397117736749$

Pavey, L., Greitemeyer, T., \& Sparks, P. (2012). I help because I want to, not because you tell me too: Empathy increases autonomously motivated helping. Personality and Social Psychology Bulletin, 38(5), 681-689. doi: $10.1177 / 0146167211435940$

Pishghadam, R., \& Zarei, S. (2012). Cross-cultural comparison of gratitude expressions in Persian, Chinese and American English. Canadian Centre of Science and Education, 5(1), 117-126. doi: 10.5539/elt.v5n1p117

Rusdi, A. (2016). Syukur dalam psikologi islam dan konstruksi alat ukurnya. Jurnal IImiah Penelitian Psikologi: Kajian Empiris \& Non-Empiris, 2(2), 37-54. doi: 10.22236/JIPP-19

Sativa, A. R., \& Helmi, A. F. (2013). Syukur dan harga diri dengan kebahagiaan remaja. WACANA, 5(10). Retrieved from http://jurnalwacana.psikologi.fk.uns.ac. id/index.php/wacana/article/view/9
Weinstein, N., \& Ryan, R. M. (2010). When helping helps: Autonomous motivation for prosocial behavior and its influence on well-being for the helper and recipient. Journal of Personality and Social Psychology, 98(2), 222-244. doi: 10.1037/a0016984

Weinstein, N., DeHaan, C. R., \& Ryan, R. M. (2010). Attributing autonomous versus introjected motivation to helpers and the recipient experience: Effects on gratitude, attitudes, and well-being. Motivation and Emotion, 34(4), 418-431. doi: 10.1007/s11031010-9183-8

Wicaksono, M., \& Susilawati, L. K. P. A. (2016). Hubungan rasa syukur dan perilaku prososial terhadap psychological well-being pada remaja akhir anggota islamic medical activists fakultas kedokteran Universitas Udayana. Jurnal Psikologi Udayana, 3(2), 196-208. Retrieved from https://ojs.unud.ac.id/index.php/psikol ogi/article/view/25234

Yoshimura, S. M., \& Berzin, K. (2017). Grateful experience and expressions: The role of gratitude expressions in the link between gratitude experiences and well-being. Review of Communication, 17(2), 106-118. doi: 10.1080/15358593.2017.1293836 